\title{
An Analysis of Political Discourse under the Communist Regime in Albania
}

\author{
Ardita Dylgjeri, Phd candidate
}

\author{
"Aleksander Xhuvani" University, Elbasan, Albania \\ E-mail: arditadylgjeri@live.com
}

\section{Doi:10.5901/ajis.2013.v2n9p177}

\begin{abstract}
The communist dictatorship created its own stereotypes in every aspect of the social and cultural life of the Albanian people for at least 45 years. It even changed elements of the Albanian language, by omitting, adding or even granting new meanings to the lexicon of our language. The acts of speech, at least during the direct regime of Enver Hoxha, were filled with clichés and formulas, which were coined to meet the changing need of social conditions as well as the need of authorities to establish control. "The wooden language", rhetorical strategies and techniques used in political discourses of that time have altered the face of Albanian culture and affected Albanian thought pattern. These interferences still can affect our language; so it is our job to study the phenomena and to know more about the mechanism that affects our language.
\end{abstract}

Keywords: political discourse, speech acts, communism, slogans, rhetorical strategies, indoctrination.

\section{Introduction}

Politics evolves alongside with the language, relying on it and utilizing it. A political phenomenon becomes tangible and discussable only after it has been expressed in words. The way political reality is perceived is therefore to a large extent determined by the basic concepts of political discourse, political formulas and clichés. Abundant academic literature describing the relations between political realias and their reflection in the language speaks for the correlation of these two phenomena: politics and political discourse. It's noteworthy, that political discourse displays "primacy of values over facts, prevalence of persuasion and evaluation over information sharing, and the emotional over the rational" (E.I.Sheigal, p. 46)

Language does not simply write and think for me, it also increasingly dictates my feelings and governs my entire spiritual being the more unquestioningly and unconsciously I abandon myself to it. And what happens if the cultivated language is made up of poisonous elements or has been made the bearer of poisons? Words can be like tiny doses of arsenic: they are swallowed unnoticed, appear to have no effect, and then after a little time the toxic reaction sets in after all. (Klemperer, 2002, p. 15)

Scholars have shown unlimited interest to how language functions in totalitarian and authoritarian societies. In political science, the term "totalitarianism" (from the Latin "totalis," entire, whole) is used to describe control over the entire social system, including all of its elements, such as people and their minds. From the point of view of communication, the most significant characteristic of the totalitarian regime is that its communication model has the format of a monologue. In other words, the ideal (toward which the society is striving) presupposes a clear, universal communicative hierarchy where one person speaks and the rest listen. Control over the dissemination of political information is an important factor in the definition of a political regime: authoritarianism and totalitarianism are characterized by a stringent control over the information flow, while democracy presupposes free public flow of information.

The main characteristic traits of totalitarianism are the ideological background and rationalization of the public consciousness, referred to by some researchers as the total politic suggestion of the mind (Vehbiu, 2007, p. 25).

\section{Wooden language in the political speech acts under totalitarism.}

The language is not only conservative, but also a democratic element of the culture of a society. The totalitarian regime encouraged the use of various elements of what is usually called "wooden language". Beyond drawing on new models that were desired but not understood, we argue that old symbols were also employed in "revolution" myth-making in the form of wooden language. As previously discussed, under the communist regime, official propaganda became increasingly severed from empirical reality. As such, the political discourse moved further and further toward what we 
consider wooden language. As Ely and Stoica argue in the Romania's case, wooden language at a first glance seems to be flowery and grandiose, yet, in the end, consists of empty words that are used to "lift the human spirit" and, at the same time, mask the reality of the situation. Anybody familiar with political discourse is familiar with wooden language to some degree (Ely \& Stoica, 2004, p. 105). Phrases such as "Albania's Brightest and Luminous Future!" still ring in the ears of many Albanians today. Marková, on her side, claims that this language appears neutral; it does not have the same capability to enrich itself. She argues even that it was not only the case of the totalitarian regime in the Soviet Union, but also in the other countries behind the Iron Curtain. Words like kulak, enemy of the class etc. became powerful gadgets used to control the masses. This power weapon not only affected societies like the Soviet one or the eastern countries, but even communists in West (Marková, 2003, p. 98).

In this framework, if we carefully consider the conveyed message, in 1981, a year in which it was very difficult for people to provide themselves with clothes and food, when food rationing had reached its peak, in the VIII Congress, Enver Hoxha declared great economical growth, increase in the circulation of goods and even in the production of cereals and other kinds of food (Hoxha, Raport i Kongresit VIII, 1981, pp. 12-13). Meanwhile he asks the people's attention to deal with the consequences of "the betrayal of the Chinese revisionists". As well as this, great importance was paid to the role of the Party and sometimes the combination "Party - Collectives", was made just to show that something new was either realized formally or not realized at all. If we took into consideration the totalitarian Albanian according to the Reiznikov`s definition of wooden language or the Newspeak described by Orwell in 1984 (Orwell, 2004, p. 383; Reznikov, 2001, pp. 42-43), we may conclude that it suffered all the characteristics given by them. The words used in the communication between the political leaders and the audience was limited in number, those mostly uttered were: the Party, leadership, Political Bureau, Social - Imperialism, Revisionism, Collectives, and New Man etc. Their original meaning had been lost and they had nothing in common with the meaning the same words had in other languages. As an instance, Hoxha's New Man was a far cry from the same noun phrase used originally in the Roman Empire, where it was firstly encountered as a concept. The New Man in Rome was a representative of Plebe, who had enough richness in his possession so as to be part of the Senate, whereas, on the contrary, Hoxha's New Man was depersonalized, without property, thought and opinion of his own, in short, he was not a human being, but a humanoid creature, whose physical appearance was the only component which made him be called an individual (Korça, 2012). The Collectives was not the human community, a social group, but instead it was a group of people without identity and belief under the leadership and the severe control of the Party.

\section{The clichés used in totalitarian language.}

Generally speaking, the discourse is developed within the framework of formulating and transmitting thought and opinions according to clear forms and schemes, closely linked to the elements of expressive logics. A totally different phenomenon occurs in a language, which develops limited expressing abilities of the individuals, based on denial of the conscious elementary right he has, freedom of speech and thought. As a result of these, there would be created some forms which do not respond to the expressive logics of a language (Vehbiu, 2007, pp. 178-179). A system which does not allow the attributes of free thought and speech has its own system of functioning, conditioning, censuring and self - censuring. Albanian language under totalitarian regime didn't have the luxury of being free, conscious and independent; so the public expressions didn`t follow certain linguistic patterns, but instead, a well - defined order in hierarchy and form. The words used as part of a typical formula of the political communication lose their role as a message and gain rhetorical nuance. From this point of view, when word perception of clichés is required, we observe that the denotation meaning becomes con notational. To provide an example, we may refer to a part of Enver Hoxha's political speech so as to observe the use of clichés in totalitarian Albanian language:

Under the Party's leadership, with unquestionable belief of its right ideology, the labor class, cooperatives peasantry, the youth and intelligence, worked hard both physically and mentally to successfully overcome the difficulties of the socialist growth, and the ones caused by the foreign enemies as well. (Hoxha, Raport i Kongresit VIII, 1981, p. 3)

In this sentence we can easily identify and analyze how the denotative meaning becomes connotative. In the years 1977 - 1981, the Party leadership, seen in a narrow point of view, denotes the Albanian Executive and Legislative, but in these case the meaning is limited to just a more privileged group of individuals who made up the Political Bureau. The "socialist growth", directly denoted the economical development, but in a wider sense of the word it referred to the improvement of living conditions, social emancipation etc. As we can see, all the phrases used in this paragraph have not only lost the messaging ability, but they have also been transformed into new elements, having lost their first meaning. 
Those lexical meanings were part of the semantic system, which could have flourished in another universe, in which the reality was not hidden after the words and phrases, whose meaning was lost in the indoctrinated minds and psychological barriers of fear. (Reznikov, 2001, p. 109)

The clichés have evidently depleted the political communication. Thus, language became the subject of ideology, rather than a means of expression. In these circumstances, the language is studied under the conditions of indoctrination and sometimes by even attributing to the main leader the qualities of a master in linguistics (Thomai, 1984, p. 174). Jani Thomai in his "Lexicology of Albanian language", estimates that in the thirty - five thousand pages published by the dictator, more than five thousand idiomatic phrases are used. He goes on with mentioning some examples such as: the water rests, the enemy doesn't, in one hand the pickax, in the other the riffle because if the enemy is given the opportunity, he stabs you. This phenomenon clearly demonstrates that the use of fixed formulas by Enver Hoxha and then their continuous repetition, handled an exponential effect. If we keep in mind the simple fact that until 1991, when the school texts were reconsidered, Hoxha`s idioms and clichés were present in these ones of every level. In such cases we may definitely understand the influence that the totalitarian regime in general and Enver Hoxha's speeches in particular had in the use and creation of formulaic language, clichés and obvious boundaries through which could and had to be conveyed the political messages.

\section{Other changes in the Albanian lexicon.}

Every social and political period of time produces its own lexicon. In these circumstances, the changes that have occurred within the English lexicon cannot be left out. Several neologisms were introduced; some words or phrases have changed either their semantic meaning or have achieved new nuances of meaning, borrowings from other languages were introduced in the existing lexicon etc. These are some of the characteristics of the Albanian lexicon under the totalitarian regime.

The language used by Enver Hoxha ranges from the use of traditional Gjirokastra`s variant of tosk dialect and some borrowed or new words which could meet the requirements of the new social context. When taking into consideration borrowings, as a vital part of the lexicon of that time, we may discuss about words such as: imperialism, revisionism, kulak, pioneer, class struggle, proletarian etc. But in all cases, despite of being borrowed words, they have also been adapted in both context and form to the Albanian case. He could use even distorted borrowed words in some cases such as inteligjencien meaning intellectual class. (Hoxha, Raport i Kongresit VIII, 1981, pp. 3,63) Or in other cases he found out kinds of Marxist divisions or revisionist fractions amongst the communist movements around the world. (Hoxha, Kundër revizionizmit modern., 1979, pp. 4-7)

On this ground, excluding the terms imperialism and revisionism, whose usage ought to and could only be developed within the same context as predicted by Marx, Stalin and Lenin; the other terms as mentioned above are detached by the original contexts of the respective languages. For instance, pioneer a person who is the first to study, develop a new area of knowledge, culture etc, a person who is the first to go somewhere and start living there etc (Oxford Dictionary, 1995), into a person who was a member, aged $10-15$, of an organization with mainly political background (Hoxha, Për arsimin, 1979, pp. 33,36,74), but with some educational elements as well. Proletarian is another term of Marxist literature whose meaning has acquired some semantic changes from a person, who in ancient Rome was so poor that had in possession just his children; into an individual who was part of the ruling class in the dictatorship of the proletariat, at least regarding the law. Another interesting case was the term kulak, obvious borrowing from the Bolshevik Russian and its usage in many cases in a perfect concordance with its roots.

Words, as comrade or patriot etc. changed their usage and in some cases even their meaning. A comrade used to be a friend; at the time in discussion, it meant anyone; the word had a social connotation, it became a way to address someone. A patriot was not a man who dedicated his everything to the country and the nation; he had to be a perfect follower of the Party directives. A worker was not only somebody who worked; he was a member of the proletariat and one that had not only the right to be part of the class struggle but had the obligation to bring it in a higher level. The volunteer was another word in Albanian that magically became a symbol of exploitation of the unpaid work of persons who were forced to do such work (Samara, 2008, p. 133).

The phraseology units were used in a great range during the political discourse. Phrases as "open hearted", "selfdenial spirit", "the water rests, the enemy doesn't", "New Albania", and "the people`s power" (Hoxha, Letra të zgjedhura, 1985, pp. 15-21) and so on others were created on the basis of the Albanian lexicon or proverbs and already in use phraseology units (Vehbiu, 2007, p. 147). In all cases their frequent usage turned them from words with a deep impact in the audience in words that were just used in formal communication. This tendency has been documented even by Jani 
Thomai (Thomai, 1984, p. 174). In such way the influence of the usage of clichés was not only encouraged by the political leadership but by the academic structures as well (Petersen, 2004, p. 16).

\section{Findings}

In a dictatorial system, the communication between the ruling caste and the population has got political and pragmatic importance. The 45- year- old history of communist dictatorship in Albania demonstrated that in most cases the communication of the political will, political message and ruling caste decisions had to be made not through common means of communication in a society, through the evolving language, but through some standard immutable forms, from the top of the political pyramid to the humblest individual. As a result of this, the population seemed to be categorized into two main groups: "us", all the patriots, communists, the members of the democratic front etc. and "them", the internal or external enemies of the class.

Thus, from the point of view of language, the totalitarian discourse displays the following dominant characteristics: "orating": prevalence of a declamatory style and a fervent cam paining tone; common usage of ideological indoctrination, attribution of symbolic meanings to core political concepts, creation of ideological expressions, borrowing of foreign concepts, modifying till alienation certain Albanian words, potentially different in meaning from the actual meaning of the words; exaggerated abstraction and scientism, active use of generalizations at the expense of logic; heightened criticism and fervor, not always genuine; slogan-like style, passion for mantras; claims to absolute truth. These truths were so absolute that nothing existed beyond them, so that no words could describe those truths that didn't exist.

\section{References}

E.I.Sheigal. Semiotics of Political Discourse,. Moscow, Volgograd,P.46.

Ely, J. F., \& Stoica, C. A. (2004). Re-membering Romania. In H. F. Carey (Ed.), Romania since 1989. Politics, Economics and Society (pp. 97-116). Oxford: Lexington Books.

Hoxha, E. (1979). Kundër revizionizmit modern. Tiranë: Instituti i studimeve Marksiste-Leniniste.

Hoxha, E. (1985). Letra të zgjedhura. Tiranë: linstituti i studimeve Marksiste-Leniniste.

Hoxha, E. (1979). Për arsimin dhe edukatën. Tiranë: Instituti i studimeve Marksiste-Leniniste.

Hoxha, E. (1979). Për arsimin dhe edukatën. Tiranë: Instituti i studimeve Marksiste-Leniniste.

Hoxha, E. (1981). Raport mbi veprimtarinë e Komitetit Qëndror të Partisë së Punës të Shqipërisë mbajtur në Kongresin e VIII-të të PPSh. Tiranë: Shtëpia Botuese "8 Nëntori".

Klemperer, V. (2002). Language of the Third Reich: LTI: Lingua Tertii Imperii: A Philologist's Notebook. (M. Brady, Trans.) Londo: Continuum.

Korça, M. (2012, September 6). Si erdhi edhe e shfytyroi shqiptarin diktatura duke krijuar njeriun "e ri socialist". Retrieved May 13, 2013, from Gazeta Metropol: http://www.gazetametropol.com/si-erdhi-edhe-e-shfytyroi-shqiptarin-diktatura-duke-krijuar-njeriun-e-risocialist/

Marková, I. (2003). Dialogicality and Social Representations: The Dynamics of Mind. Cambridge: Cambridge University press.

Orwell, G. (2004). 1984. Fairfield, U.K.: 1stworldlibrary.org.

Oxford Advanced Learner's Dictionary (Fitth edition ed.). (1995). Oxford University Press.

Petersen, J. (2004). The history of the concept Totalitarianism in Italy. In H. Maier (Ed.), Totalitarianism and Political Religions (J. Bruhn, Trans., Vol. 1, pp. 3-21). London: Routledge.

Reznikov, A. (2001). George Orwell's Theory of Language. Lincoln, Nebraska, U.S.A: Writers Club Press.

Samara, M. (2008). Rreth leksikut politik e shoqëror në gjuhën shqipe: Vështrim leksikologjik e leksikografik. Tiranë: Akademia e Shkencave e Shqipërisë .

Thomai, J. (1984). Leksikologjia e gjuhës shqipe. Tiranë: Universiteti i Tiranës, Fakulteti i Historisë dhe i Filologjisë.

Vehbiu, A. (2007). Shqipja totalitare. Tipare të ligjërimit publik në Shqipërinë e viteve 1945-1990. Tiranë, Shqipëri: Botime Çabej 